Jurnal Riset Manajemen dan Akuntansi

Volume 1 - No.2, Oktober 2014

\title{
ANALISIS RETURN DAN LIKUIDITAS SAHAM SEBELUM DAN SESUDAH PENGUMUMAN RIGHT ISSUE DI BURSA EFEK INDONESIA
}

\author{
Irdha Yusra \\ Sekolah Tinggi Ilmu Ekonomi KBP \\ (irdhayusra@gmail.com)
}

\begin{abstract}
The purpose of this study was to analyze the abnormal returns and trading volume activity before and after the announcement of the rights issue. This research is the event study using secondary data. 33 companies listed in Indonesia Stock Exchange from 2005 to 2009 were sampled using a purposive sampling method, which consists of 9 samples (good news) and 24 samples (bad news).

The results of this study showed that there was no significant difference in abnormal return observation period 5 days, 15 days, 60 days, 90 days, 180 days before and after the announcement of the rights issue in the group of good news and bad news. While the volume of trading activity, trading volume activity differences are significant at the 5 day period prior to the announcement of the rights issue after the group bad news.
\end{abstract}

Keyword: Return, Liquidity and event study

\section{PENDAHULUAN}

Dalam pasar modal, perkembangan harga saham dan volume perdagangan adalah suatu indikator yang penting untuk mempelajari tingkah laku pasar. Dalam menen-tukan apakah investor akan mela-kukan transaksi di pasar modal atau tidak, biasanya keputusan didasarkan pada berbagai informasi yang dimilikinya, baik informasi yang tersedia di publik maupun informasi pribadi. Informasi tersebut akan memiliki nilai bagi investor, sebab informasi tersebut dapat mengindi-kasikan adanya informasi yang menguntungkan (good news) atau informasi yang tidak menguntungkan (bad news) tentang kondisi laba di masa akan datang. Informasi yang menguntungkan (good news) untuk perusahaan yang mempunyai actual return positif yang dianggap menguntungkan sedangkan bad news untuk perusahaan yang mempunyai actual return 0 (nol) atau negatif yang dianggap merugikan atau tetap. Hal ini dapat menyebabkan preferensi investor untuk melakukan transaksi di pasar modal.

Perusahaan membutuhkan mo-dal untuk tumbuh dan memperoleh tambahan aset. Biasanya perusahaan membeli aset jangka panjang dengan menggunakan modal jangka panjang. Salah satu sumbernya berasal dari laba yang ditahan. Ketika modal yang dibutuhkan lebih besar daripada kemampuan perusahaan untuk menghasilkan dana secara internal, maka pada saat itu perusahaan akan membutuhkan dana secara eksternal (Yusi, 2002). Ada beberapa usaha yang 
dapat dilakukan perusahaan dalam rangka memperoleh dana. Salah satunya adalah dengan mela-kukan penjualan saham kepada masyarakat, yang dikenal dengan istilah go public.

Perusahaan yang sudah terdaftar di pasar modal ada kalanya membutuhkan dana segar lagi jika sumber internal maupun pinjaman dari bank dianggap kurang memadai atau menguntungkan. Perusahaan dapat melakukan penawaran saham lagi kepada investor baik melalui penawaran umum maupun penawaran terbatas. Pada penawaran umum saham ditawarkan kepada para investor secara keseluruhan, sedangkan penawaran terbatas saham ditawarkan kepada pemegang saham lama dengan harga yang umumnya lebih rendah dibanding dengan harga saham sebelum right issue. Right issue harus digunakan terlebih dahulu oleh pemegang saham lama Sunyoto ,2001). Jika dia tidak menggunakan haknya untuk membeli, maka saham baru tersebut ditawarkan kepada pihak lain.

Right issue merupakan salah satu cara yang dilakukan oleh perusahaan yang telah terdaftar (listed) di bursa efek untuk memperoleh dana (Solichin,2003). Istilah right issue di Indonesia dikenal pula dengan istilah Hak Memesan Efek Terlebih Dahulu (HMETD). Right issue merupakan pengeluaran saham baru dalam rangka penam-bahan modal perusahaan, namun terlebih dahulu ditawarkan kepada pemegang saham saat ini (existing shareholder). Dengan kata lain, pemegang saham memiliki hak preemptive rights atau Hak Memesan Efek Terlebih Dahulu (HMETD) atas saham-saham baru tersebut. Tentu saja untuk mendapatkan saham tersebut, pemegang saham harus melaksanakan rights tersebut pada tingkat harga yang telah ditentukan.
Menurut Fahmi dan Yovi (2009:94) karena sifatnya hak, maka investor tidak terikat untuk membelinya, yang artinya jika investor tidak mau menggunakan haknya, maka dia dapat menjual right tersebut. Dengan demikian terjadilah perdagangan atas right.

Dalam penelitian ini, return dan volume perdagangan saham perusahaan dikelompokkan berdasarkan dua kondisi yang berbeda yaitu kelompok saham good news dan kelompok saham bad news. Hal ini dilakukan untuk mengetahui dampak dari pengumuman right issue terhadap saham-saham yang mempu-nyai tanggap investor berbedabeda, sebagai cerminan atas pengharapan investor yang berbeda pula.

Pendanaan melalui right issue memberikan reaksi pasar ganda bagi fluktuasi harga saham. Harga saham akan berfluktuasi setelah masa berlaku penawaran (cum date) atau saat penawaran tidak berlaku lagi (ex date). Ini terjadi karena investor bersifat mengantisipasi informasi yang memberikan indikasi positif maupun negatif (Yusi,2002).

Pengumuman perusahaan yang melakukan right issue, secara teoritis dan empiris telah mengakibatkan harga saham bereaksi negatif dan ini merupakan kejadian yang diakibatkan oleh systematic risk. Systematic risk adalah bagian risiko yang tidak dapat dihilangkan dengan melakukan diversifikasi atas portofolionya. Tandelilin (2001:60) menyatakan bahwa diversifikasi dalam pernyataan tersebut bisa bermakna bahwa investor perlu membentuk portopolio sedemikian rupa hingga risiko dapat diminimalkan tanpa mengurangi return yang diharapkan. Mengurangi risiko tanpa mengurangi return adalah tujuan investor dalam berinvestasi. 
Penelitian ini bertujuan untuk menguji apakah pengumuman right issue yang dipublikasikan akan mempengaruhi pengambilan keputusan investor. Ada tidaknya pengaruh akan dilihat dengan perubahan harga/return dan volume perdagangan saham di seputar tanggal pengumuman. Untuk mengetahui hal tersebut akan dilakukan pengujian dengan menggunakan metodologi event studies(Tandelilin, 2001).

\section{KERANGKA TEORITIS DAN HIPOTESIS}

Pasar saham dikatakan efisien jika penyesuaian harga terjadi secara cepat atas kedatangan informasi baru dan harga saham merefleksikan semua informasi relevan yang tersedia (Jogianto, 2000; Scott, 2003; Tandelilin, 2010). Dalam hal ini, informasi yang tersedia bisa meliputi semua informasi yang tersedia baik informasi di masa lalu dan informasi saat ini. Biasanya informasi lengkap tentang perusahaan dimiliki oleh manajemen perusahaan. Namun, informasi yang ada sering kali tersebar secara tidak merata. Dimana ada suatu pihak yang telah mengetahui informasi perusahaan terlebih dahulu sebelum informasi dipublikasikan (asymmetric infor-mation). Asymmetric information muncul ketika manajer lebih mengetahui informasi internal dan prospek perusahaan dimasa yang akan datang dibandingkan pemegang saham dan stakeholder lainnya (Budiarto dan Baridwan, 1999; Hanafi, 2004; Chae, 2005; Manurung, 2012; Sartono, 1996; Raharja dan Maylia, 2008).

Akibat adanya asimetri informasi, harga saham yang terjadi belum mencapai harga ekuilibrium sehingga investor yang mempunyai informasi yang tahu bahwa harga ekuilibrium akan mencapai titik tertentu akan membeli sekuritas tersebut dan nantinya akan menjualnya pada harga ekuilibrium sehingga dapat menikmati abnormal return selisih harga saham tersebut.

Jogiyanto (2000:392), informasi yang dipublikasikan sebagai suatu pengumuman akan memberikan signal bagi investor dalam pengambilan keputusan investasi (signalling theory). Pengumuman dapat berupa signal positif (good news) ataupun negatif (bad news.) Signal positif (good news) untuk perusahaan yang mempunyai return aktual (actual return) positif yang dianggap menguntungkan dan kelompok signal negatif (bad news) untuk perusahaan yang mempunyai return aktual (actual return) 0 (nol) atau negatif yang dianggap merugikan atau tetap.

Sinyal terhadap informasi adanya peristiwa (event) tertentu dapat mempengaruhi nilai perusahaan yang tercermin dari perubahan harga dan volume perdagangan saham yang terjadi (Budiarto dan Baridwan, 1999). Implikasinya, pengumuman perusahaan untuk menambah jumlah lembar saham baru yang beredar (right issue) akan direspon oleh pasar sebagai suatu sinyal yang menyam-paikan adanya informasi baru yang dikeluarkan pihak manajemen yang selanjutnya akan mempengaruhi nilai saham perusahaan dan aktivitas perdagangan saham. Setelah pener-bitan rights, jumlah lembar saham akan meningkat. Umumnya dengan adanya penambahan jumlah lembar saham yang beredar di pasar maka akan meningkatkan volume perdaga-ngan saham tersebut, dengan kata lain penambahan tersebut akan mening-katkan likuiditas saham (Husnan dan Pudjiastuti, 2006).

Penelitian ini akan membeda-kan saham dalam kondisi yang berbeda. Kondisi pertama yaitu dimana pasar memberikan reaksi positif melalui perubahan harga saham yang semakin 
meningkat karena pengumuman right issue merupakan suatu berita baik (good news) bagi investor untuk berinvestasi dalam dana right issue dan sebaliknya, pada kondisi kedua yakni pasar akan memberikan reaksi negatif atau tidak bereaksi dengan indikasi perubahan harga saham yang semakin menurun atau tetap karena pengumuman right issue merupakan suatu berita buruk (bad news) atau bukan merupakan informasi yang berarti bagi investor dalam mengambil keputusan berinvestasi.

Zulfadli (2009) melakukan penelitian tentang analisis return saham sebelum dan sesudah right issue pada perusahaan go public di Bursa Efek Indonesia tahun 2005-2009, hasil penelitiannya menunjukan bahwa terdapatnya abnormal return positif yang signifikan sebelum right issue pada periode 90 dan 180 hari, dan tidak terdapat perbedaan abnormal return yang signifikan antara periode pengamatan 5 hari, 15 hari, 90 hari dan 180 hari sebelum dan sesudah right issue terhadap abnormal return. Sedangkan periode pengamatan 30 har i sebelum dan sesudah right issue, terdapat perbedaan yang signifikan terhadap abnormal return saham. Hasil penelitian ini menunjukkan bahwa dengan terdapat abnormal return maka tidak terdapat pasar efisien dalam bentuk setengah kuat dan rata-rata abnormal return sebelum dan rata-rata abnormal return sesudah right issue relative tidak memiliki perbedaan yang signifikan.

Penelitian yang dilakukan oleh Budiarto dan Baridwan (1999) menyatakan bahwa tidak ada perbedaan yang signifikan pada return saham, abnormal return dan kegiatan volume perdagangan tanggal pengumuman right issue.

Berlianta pada tahun 1995 (dalam Solichin, 2003), melakukan penelitian tentang perilaku harga saham saat perusahaan melakukan penawaran saham terbatas untuk sampel perusahaan yang terdapat di Bursa Efek Jakarta. Perusahaan yang digunakan sebagai sampel adalah perusahaan yang melakukan right issue tahun 1993 dan 1994, dan pengumuman yang digunakan adalah pengumuman di surat kabar. Penelitian tersebut menghasilkan adanya return positif dan signifikan pada saat pengumuman tetapi tidak didapatkan abnormal return yang positif satu hari setelah pengumuman.

Penelitian sejenis dilakukan Widjaja pada tahun 2000 (dalam Yusi ,2001), menemukan bahwa pengumuman right issue cenderung menimbulkan respon negatif pada tanggal diumumkannya right issue dan di sekitar tanggal pengumuman right issue tersebut (short event window). Sedangkan dalam periode penga-matan jangka panjang (long event window), pengumuman right issue cenderung menimbulkan respon pasar positif.

Siswanto (1999) mengambil sampel 24 perusahaan yang terdaftar di Bursa Efek Jakarta (BEJ) dan melakukan right issue antara tahun 1997 sampai tahun 1999. Mereka mengemukakan pengumuman right issue tidak berpengaruh terhadap harga saham dan tingkat keuntungan saham, akan tetapi berpengaruh negatif terhadap likuiditas saham yang menyebabkan likuiditasnya menurun. Pada penelitian tersebut pengumuman right issue tidak mem-pengaruhi pengambilan keputusan investor, bahkan investor lebih cenderung mengabaikan adanya pengumuman right issue tersebut.

Dari penjelasan dan hasil kajian di atas, maka dirumuskan hipotesis sebagai berikut:

$\mathbf{H}_{1}$ : Abnormal return saham sebelum pengumuman right issue berbeda secara signifikan 


dengan abnormal return
sesudah pengumuman
issue pada kelompok
good newam

$\mathbf{H}_{2}$ : Abnormal return saham sebelum pengumuman right issue berbeda secara signifikan dengan abnormal return sesudah pengumuman right issue pada kelompok sahambad news.

$\mathbf{H}_{3}$ : Volume aktivitas perdagangan saham sebelum pengumuman right issue berbeda secara signifikan dengan volume aktivitas perdagangan sesudah pengumuman right issue pada kelompok saham good news.

$\mathbf{H}_{4}$ : Volume aktivitas perdagangan saham sebelum pengumuman right issue berbeda secara signifikan dengan volume aktivitas perdagangan sesudah pengumuman right issue pada kelompok saham bad news.

\section{METODOLOGI}

\section{Data dan Sampel}

Dalam penelitian ini yang menjadi populasi adalah semua perusahaan yang terdaftar di BEI serta mengumumkan right issue pada tahun 2005 sampai dengan 2009, yang berjumlah 94 perusahaan.Sampel penelitian yang digunakan diambil dengan menggunakan metode purposive sampling, kriteria dalam pemilihan sampel adalah (1) Tersedianya data tanggal pengu-muman right issue, dan data perda-gangan saham (closing price dan volume perdagangan) harian, (2) Perusahaan yang hanya melakukan kebijakan right issue, sehingga jika pada tahun yang bersamaan perusahaan melakukan kebijakan corporate action seperti stock split, dividen saham, dan peristiwa yang lain yang dapat mempengaruhi harga saham dan jumlah saham yang beredar, maka perusahan tersebut keluar dari sampel. Dari kriteria tersebut, ditemukan sebanyak 33 sampel perusahaan yang akan diteliti selama periode pengamatan.

\section{MetodeAnalisis Data}

Penelitian ini menggunakan metode event study (studi peristiwa). Studi peristiwa merupakan studi yang mempelajari pengaruh suatu peristiwa terhadap harga saham di pasar, baik pada saat peristiwa itu terjadi maupun beberapa saat setelah peristiwa itu terjadi (Samsul, 2006). Event studies ini menguji reaksi investor dan pasar terhadap peristiwa rightissue. Penelitian eventstudy umumnya berkaitan dengan seberapa cepat suatu informasi yang masuk ke pasar dapat tercermin pada harga saham (Tandelilin, 2001).

Teknik studi peristiwa ini menggunakan windowsperiod selama 5 hari, 15 hari, 60 hari, 90 hari, dan 180 hari sebelum dan sesudah pengumuman rightissue pemilihan windowsperiod ini karena rightissue biasanya memiliki jangka waktu 6 bulan sebelum para investor berhak memakai haknya atas right tersebut dan bertujuan untuk melihat nilai abnormal return sebelum rightissue dan sesudah rightissue, apakahbernilaipositifataunegatif. Jika bernilai positif berarti bahwa rightissue menginformasikan sinyal yang baik (goodnews) bagi investor dan sebaliknya, jika abnormalreturn berbilai negatif maka informasi rightissue menginformasikan sinyal yang buruk (badnews) bagi investor.

Model yang digunakan dalam penelitian ini adalah market model. Adapun langkah-langkah pengolahan datanya adalah sebagai berikut :

A. Periode estimasi (estimation period)

1. Menghitung return saham aktual individual (actual return) harian.

$$
R_{i t}=\frac{P_{i t}-P_{i t-1}}{P_{i t-1}}
$$


Dimana:

$R_{i t} \quad$ : Aktual Return saham masing-masing perusahaan

$P_{i t} \quad$ : Harga saham masingmasing perusahaan pada tanggal $\mathrm{t}$

$P_{i t-1}$ : Harga saham masingmasing perusahaan pada tanggal $\mathrm{t}-1$

2. Menghitung return pasar harian.

$$
R_{m t}=\frac{I H S G_{t}-I H S G_{t-1}}{I H S G_{t-1}}
$$

Dimana:

$R_{m t} \quad$ : Return pasar

$I H S G_{t}$ : Indeks Harga Saham Gabungan pada tanggal $\mathrm{t}$

$I H S G_{t-1}$ : Indeks Harga Saham Gabungan pada tanggal t-1

3. Meregresikan return saham harian (actual return) dengan return pasar harian (return market) guna memperoleh $\alpha$ dan $\beta$ masing-masing saham. Besarnya $\alpha$ dan $\beta$ ditetapkan dengan menggunakan Ordi-nary Least Square (OLS), dengan rumus :

$$
\begin{aligned}
& \alpha=\frac{\Sigma Y-\beta(\Sigma X)}{n} \\
& \beta=\frac{n(\Sigma X Y)-(\Sigma X)(\Sigma Y)}{n\left(\Sigma X^{2}\right)-(\Sigma X)^{2}}
\end{aligned}
$$

Adapun persamaan regresinya adalah sebagai berikut:

$$
\mathbf{Y}=\boldsymbol{\alpha}+\boldsymbol{\beta} \boldsymbol{X}
$$

Dimana:

$$
\begin{array}{ll}
\mathrm{X} & \text { : Return pasar }\left(\mathrm{R}_{\mathrm{mt}}\right) \\
\mathrm{Y} & \text { : Return saham }\left(\mathrm{R}_{\mathrm{it}}\right) \\
\mathrm{n} & \text { : Jumlah hari }
\end{array}
$$

B. Periode Kejadian(Event Period)

1. Menghitung return saham harian individual (actual return), kemudian diklasifikasikan menjadi dua kelompok. Untuk rata-rata actual return yang positif diklasifikasikan dalam kelompok good news, sedangkan untuk rata-rata actual return nol dan negatif diklasifikasikan dalam kelompok bad news.

2. Menghitung return pasar harian

3. Menghitung expected return selama event period dengan menggunakan $\alpha$ dan $\beta$ periode estimasi.

$$
(\mathbf{E}) \mathbf{R}_{\mathrm{it}}=\alpha+\boldsymbol{\beta}_{j} \boldsymbol{R}_{\mathrm{mt}}
$$

Dimana:

$(\mathrm{E}) \mathrm{R}_{\mathrm{it}} \quad$ : Expected return

$R_{\mathrm{mt}} \quad$ : Return pasar

yang sesungguhnya

$\begin{array}{lll}\alpha, \beta & : \quad \text { Koefisien } \\ \text { regresi } & & \end{array}$

4. Menghitung abnormal return $\left(\mathrm{AR}_{\mathrm{it}}\right)$ harian individual, dengan menggunakan market model dengan persamaan sebagai berikut:

$$
\mathrm{AR}_{\mathrm{it}}=\mathbf{R}_{\mathrm{it}}-(\mathbf{E}) \mathbf{R}_{\mathrm{it}}
$$

Dimana:

$\mathrm{AR}_{\mathrm{it}} \quad$ : Abnormal return harian individual

$\mathrm{R}_{\mathrm{it}}$ : Return saham

sesungguhnya

(E) $\mathrm{R}_{\mathrm{it}}$ : Expected return

6. Menghitung rata-rata abnormal return harian

$$
\operatorname{AAR}_{\mathrm{t}}=\frac{1}{n} \Sigma A R_{\text {it }}
$$

Dimana:

$\mathrm{AAR}_{\mathrm{t}}$ : Rata-rata abnormal return harian

$\mathrm{AR}_{\mathrm{it}}$ : Abnormal return harian individual

$\mathrm{n}$
perusahaan

7. Likuiditas Saham

Likuiditas saham yang tercermin melalui perubahan 
aktivitas perdagangan saham dihitung dengan menggunakan indikator Trading Volume Activity (TVA) masing-masing saham.

8. SetelahTVA masing-masing saham diketahui kemudian dihitung rata-rata volume perdagangan saham sebelum dan sesudah pengumuman right issue dalam periode pengamatan dalam penelitian untuk semua sampel dihitung dengan persamaan sebagai berikut :

$X T V A=\frac{\sum_{i=1}^{n} T V A}{N}$

TVA digunakan untuk melihat apakah preferensi investor secara individual menilai pengumuman right issue sebagai sinyal positif atau negatif untuk membuat keputusan perdagangan saham diatas keputusan perdagangan yang normal.

9. Menguji signifikansi rata-rata abnormal return dan rata-rata TVA masing-masing hari pada event window dan menguji signifikansi rata-rata abnormal return dan rata-rata TVA sebelum dan sesudah pengumuman right issue pada event window (good-bad news)digunakan program SPSS (Stastical Program for SocialScience) dengan menggunakan paired sampel $t$ test (Idris (2006).

\section{HASIL DAN PEMBAHASAN \\ Hasil}

Pegujian terhadap abnormal return dan trading volume activity menggunakan uji beda 2 rata-rata. Pengujian dilakukan dengan menggunakan windows period yaitu 5 hari sebelum dan sesudah right issue, 15 hari sebelum dan sesudah right issue, 60 hari sebelum sesudah right issue, 90 hari sebelum dan sesudah right issue, serta 180 hari sebelum dan sesudah right issue.

a. Abnormal return sebelum dan sesudah pengumuman right issue

Hasil perhitungan rata-rata abnormal return dengan menggunakan uji beda 2 rata-rata selama 5 hari sebelum dan 5 hari sesudah right issue, 15 hari sebelum dan 15 hari sesudah right issue, 60 hari sebelum dan 60 hari sesudah right issue, 90 hari sebelum dan 90 hari sesudah right issue, serta 180 hari sebelum dan 180 hari sesudah pengumuman right issue dapat dilihat pada tabel.

Tabel 1 memperlihatkan perhitungan paired sample t-test terhadap average abnormal return (AAR). Nilai rata-rata dari AAR 5 hari sebelum dan sesudah right issue pada kelompok good news adalah sebesar $-0,002$ dan $-0,017$. Untuk nilai $t_{\text {hitung }}$ AAR $(t=5)$ sebesar 0,599 yang berada di dalam t-tabel 2 sisi 0,05 (2,0345). Nilai signifikansi (2-tailed) sebesar 0,565 , yang berarti lebih besar dari nilai alpha 0,05 . Sedangkan nilai rata-rata dari AAR 5 hari sebelum dan sesudah right issue pada kelompok bad news adalah sebesar $-0,008$ dan -0,016. Untuk nilai $\mathrm{t}_{\text {hitung }}$ AAR $(\mathrm{t}=5)$ sebesar 0,878 yang berada di dalam t-tabel 2 sisi 0,05 (2,0345). Nilai signifikansi (2tailed) sebesar 0,389, yang berarti lebih besar dari nilai alpha 0,05 . Dengan demikian, dapat disimpulkan bahwa tidak terdapat perbedaan yang signifikan antara nilai rata-rata dari AAR 5 hari sebelum dan sesudah right issue pada kelompok good news dan bad news. 
Hasil perhitungan untuk periode pengamatan 15 hari memperlihatkan bahwa nilai ratarata dari AAR 15 hari sebelum dan sesudah right issue pada kelompok good news adalah sebesar -0,002 dan $-0,007$. Untuk nilai $t_{\text {hitung }}$ AAR $(\mathrm{t}=15)$ sebesar 0,502 yang berada di dalam t-tabel 2 sisi $0,05 \mathrm{e}^{`}$ $(2,0345)$. Nilai signifikansi (2tailed) sebesar 0,529, yang berarti lebih besar dari nilai alpha 0,05. Sedangkan nilai rata-rata dari AAR 15 hari sebelum dan sesudah right issue pada kelompok bad news adalah sebesar -0,001 dan -0,007. Untuk nilai $t_{\text {hitung }}$ AAR $(t=15)$ sebesar 2,034 yang berada di dalam t-tabel 2 sisi 0,05 (2,0345). Nilai signifikansi (2-tailed) sebesar 0,054 , yang berarti lebih besar dari nilai alpha 0,05 . Dengan demikian, dapat disimpulkan bahwa tidak terdapat perbedaan yang signifikan antara nilai rata-rata dari AAR 15 hari sebelum dan sesudah right issue pada kelompok good news dan bad news.
Untuk hasil perhitungan AAR $(\mathrm{t}=60)$. Nilai rata-rata dari AAR 60 hari sebelum dan sesudah right issue pada kelompok good news adalah sebesar $\quad-0,001$ dan 0,004. Untuk nilai thitung AAR $(\mathrm{t}=60)$ sebesar 0,629 yang berada di dalam t-tabel 2 sisi $0,05(2,0345)$. Nilai signifikansi (2-tailed) sebesar 0,547 , yang berarti lebih besar dari nilai alpha 0,05. Sedangkan nilai rata-rata dari AAR 60 hari sebelum dan sesudah right issue pada kelompok bad news adalah sebesar 0,000 dan $-0,002$. Untuk nilai thitung AAR ( $\mathrm{t}=60)$ sebesar 0,925 yang berada di dalam t-tabel 2 sisi 0,05 $(2,0345)$. Nilai signifikansi (2tailed) sebesar 0,365, yang berarti lebih besar dari nilai alpha 0,05. Dengan demikian, dapat disimpulkan bahwa tidak terdapat perbedaan yang signifikan antara nilai rata-rata dari AAR 60 hari sebelum dan sesudah right issue pada kelompok good news dan bad news.

Tabel 1

Paired Sample T-Test Abnormal Return

Perusahaan yang Melakukan Right Isuue tahun 2005-2009

\begin{tabular}{|l|l|l|l|l|l|l|}
\hline & & & $\mathrm{N}$ & Mean & $\mathrm{t}$ & $\begin{array}{l}\text { Sig.(2- } \\
\text { tailed) }\end{array}$ \\
\hline Pair 1 & Good news & AARtmin5 & 9 & -0.002 & 0.599 & 0.565 \\
\hline & & AARtplus5 & 9 & -0.017 & & \\
\hline & Bad news & AARtmin5 & 24 & -0.008 & 0.878 & 0.389 \\
\hline & & AARtplus5 & 24 & -0.016 & & \\
\hline Pair 2 & Good news & AARtmin15 & 9 & -0.002 & 0.502 & 0.629 \\
\hline & & AARtplus15 & 9 & -0.007 & & \\
\hline & Bad news & AARtmin15 & 24 & -0.001 & 2.034 & 0.054 \\
\hline & & AARtplus15 & 24 & -0.007 & & \\
\hline Pair 3 & Good news & AARtmin60 & 9 & -0.001 & 0.629 & 0.547 \\
\hline & & AARtplus60 & 9 & -0.004 & & \\
\hline & Bad news & AARtmin60 & 24 & 0.000 & 0.925 & 0.365 \\
\hline & & AARtplus60 & 24 & -0.002 & & \\
\hline Pair 4 & Good news & AARtmin90 & 9 & 0.000 & 1.332 & 0.220 \\
\hline & & AARtplus90 & 9 & -0.003 & & \\
\hline & Bad news & AARtmin90 & 24 & 0.000 & -0.257 & 0.799 \\
\hline
\end{tabular}




\begin{tabular}{|l|l|l|l|l|l|l|}
\hline & & AARtplus90 & 24 & -0.001 & & \\
\hline Pair 5 & Good news & AARtmin180 & 9 & -0.001 & 0.851 & 0.420 \\
\hline & & AARtplus180 & 9 & -0.003 & & \\
\hline & Bad news & AARtmin180 & 24 & 0.000 & 1.444 & 0.162 \\
\hline & & AARtplus180 & 24 & -0.002 & & \\
\hline
\end{tabular}

Sumber: Hasil Olahan SPSS

Pada hasil perhitungan AAR $(\mathrm{t}=90)$. Nilai rata-rata dari AAR 90 hari sebelum dan sesudah right issue pada kelompok good news adalah sebesar $\quad 0,000$ dan 0,003 . Untuk nilai $t_{\text {hitung }} \mathrm{AAR}$ $(\mathrm{t}=90)$ sebesar 1,332 yang berada di dalam t-tabel 2 sisi $0,05(2,0345)$. Nilai signifikansi (2-tailed) sebesar 0,220 , yang berarti lebih besar dari nilai alpha 0,05 . Sedangkan nilai rata-rata dari AAR 90 hari sebelum dan sesudah right issue pada kelompok bad news adalah sebesar 0,000 dan $-0,001$. Untuk nilai $t_{\text {hitung }}$ AAR ( $\mathrm{t}=90)$ sebesar $-0,257$ yang berada di dalam t-tabel 2 sisi 0,05 (2,0345). Nilai signifikansi (2tailed) sebesar 0,799, yang berarti lebih besar dari nilai alpha 0,05 . Dengan demikian, dapat disimpulkan bahwa tidak terdapat perbedaan yang signifikan antara nilai rata-rata dari AAR 90 hari sebelum dan sesudah right issue pada kelompok good news dan bad news.

Tabel 1 juga memper-lihatkan AAR ( $t=180)$. Nilai rata-rata dari AAR 180 hari sebelum dan sesudah right issue pada kelompok good news adalah sebesar -0,001 dan $-0,003$. Untuk nilai $t_{\text {hitung }}$ AAR $(\mathrm{t}=180)$ sebesar 0,851 yang berada di dalam t-tabel 2 sisi 0,05

\section{Tabel 2}

Paired Sample T-Test Trading Volume Activity

Perusahaan yang Melakukan Right Isuue tahun 2005-2009

\begin{tabular}{|l|l|l|l|l|l|l|}
\hline & & & $\mathrm{N}$ & Mean & $\mathrm{t}$ & $\begin{array}{l}\text { Sig.(2- } \\
\text { tailed) }\end{array}$ \\
\hline Pair 1 & Good news & ATVAtmin5 & 9 & 0.978 & 1.789 & 0.111 \\
\hline & & ATVAtplus5 & 9 & 0.844 & & \\
\hline
\end{tabular}

$(2,0345)$. Nilai signifikansi (2tailed) sebesar 0,420, yang berarti lebih besar dari nilai alpha 0,05 . Sedangkan nilai rata-rata dari AAR 180 hari sebelum dan sesudah right issue pada kelompok bad news adalah sebesar 0,000 dan 0,002. Untuk nilai $t_{\text {hitung }} \mathrm{AAR}$ $(\mathrm{t}=180)$ sebesar 1,444 yang berada di dalam t-tabel 2 sisi 0,05 $(2,0345)$. Nilai signifikansi (2tailed) sebesar 0,162, yang berarti lebih besar dari nilai alpha 0,05. Dengan demikian, dapat disimpulkan bahwa tidak terdapat perbedaan yang signifikan antara nilai rata-rata dari AAR 180 hari sebelum dan sesudah right issue pada kelompok good news dan bad news.

\section{b. Trading volume activity sebelum dan sesudah pengumuman right issue}

Hasil perhitungan rata-rata trading volume activity dengan menggunakan uji beda 2 rata-rata selama 5 hari sebelum dan 5 hari sesudah right issue, 15 hari sebelum dan 15 hari sesudah right issue, 60 hari sebelum dan 60 hari sesudah right issue, 90 hari sebelum dan 90 hari sesudah right issue, serta 180 hari sebelum dan 180 hari sesudah pengumuman right issue dapat dilihat pada tabel 2 di bawah ini. 


\begin{tabular}{|l|l|l|l|l|l|l|}
\hline & Bad news & ATVAtmin5 & 24 & 0.750 & -2.318 & 0.030 \\
\hline & & ATVAtplus5 & 24 & 0.833 & & \\
\hline Pair 2 & Good news & ATVAtmin15 & 9 & 0.904 & 1.152 & 0.283 \\
\hline & & ATVAtplus15 & 9 & 0.844 & & \\
\hline & Bad news & ATVAtmin15 & 24 & 0.792 & -2.066 & 0.050 \\
\hline & & ATVAtplus15 & 24 & 0.864 & & \\
\hline Pair 3 & Good news & ATVAtmin60 & 9 & 0.902 & 1.813 & 0.107 \\
\hline & & ATVAtplus60 & 9 & 0.806 & & \\
\hline & Bad news & ATVAtmin60 & 24 & 0.758 & -0.555 & 0.584 \\
\hline & & ATVAtplus60 & 24 & 0.781 & & \\
\hline Pair 4 & Good news & ATVAtmin90 & 9 & 0.905 & 1.541 & 0.162 \\
\hline & & ATVAtplus90 & 9 & 0.807 & & \\
\hline & Bad news & ATVAtmin90 & 24 & 0.731 & -0.679 & 0.504 \\
\hline & & ATVAtplus90 & 24 & 0.761 & & \\
\hline Pair 5 & Good news & ATVAtmin180 & 9 & 0.882 & 1.020 & 0.338 \\
\hline & & ATVAtplus180 & 9 & 0.823 & & \\
\hline & Bad news & ATVAtmin180 & 24 & 0.719 & -0.435 & 0.668 \\
\hline & & ATVAtplus180 & 24 & 0.739 & & \\
\hline
\end{tabular}

Sumber: Hasil Olahan SPSS

Tabel 1 memperlihatkan perhitungan paired sample t-test terhadap average trading volume activity (ATVA). Nilai rata-rata dari ATVA 5 hari sebelum dan sesudah right issue pada kelompok good news adalah sebesar 0,978 dan 0,844. Untuk nilai $t_{\text {hitung }}$ ATVA $(\mathrm{t}=5)$ sebesar 1,789 yang berada di dalam t-tabel 2 sisi 0,05 (2,0345). Nilai signifikansi (2tailed) sebesar 0,111, yang berarti lebih besar dari nilai alpha 0,05. Sedangkan nilai rata-rata dari ATVA 5 hari sebelum dan sesudah right issue pada kelompok bad news adalah sebesar 0,750 dan 0,833 . Untuk nilai $t_{\text {hitung }}$ ATVA $(\mathrm{t}=5)$ sebesar $-2,318$ yang berada di dalam t-tabel 2 sisi $0,05(2,0345)$. Nilai signifikansi (2-tailed) sebesar 0,030, yang berarti lebih kecil dari nilai alpha 0,05 . Dengan demikian, dapat disimpulkan bahwa tidak terdapat perbedaan yang signifikan antara nilai rata-rata dari ATVA 5 hari sebelum dan sesudah right issue pada kelompok good news dan terdapat perbedaan yang signifikan antara nilai rata-rata dari ATVA 5 hari sebelum dan sesudah right issue pada kelompok bad news.

Hasil perhitungan untuk periode pengamatan 15 hari memperlihatkan bahwa nilai ratarata dari ATVA 15 hari sebelum dan sesudah right issue pada kelompok good news adalah sebesar 0,904 dan 0,844. Untuk nilai $t_{\text {hitung }}$ ATVA $(t=15)$ sebesar 1,152 yang berada di dalam t-tabel 2 sisi $0,05 \quad(2,0345) . \quad$ Nilai signifikansi (2-tailed) sebesar 0,283 , yang berarti lebih besar dari nilai alpha 0,05 . Sedangkan nilai rata-rata dari ATVA 15 hari sebelum dan sesudah right issue pada kelompok bad news adalah sebesar 0,792 dan 0,864. Untuk nilai $t_{\text {hitung }}$ ATVA ( $\left.\mathrm{t}=15\right)$ sebesar 2,066 yang berada di dalam t-tabel 2 sisi 0,05 (2,0345). Nilai signifikansi (2-tailed) sebesar 0,050 , yang berarti sama dengan nilai alpha 0,05 . Dengan demikian, dapat disimpulkan bahwa tidak 
terdapat perbedaan yang signifikan antara nilai rata-rata dari ATVA 15 hari sebelum dan sesudah right issue pada kelompok good news dan bad news.

Untuk hasil perhitungan ATVA ( $\mathrm{t}=60)$. Nilai rata-rata dari ATVA 60 hari sebelum dan sesudah right issue pada kelompok good news adalah sebesar $\quad 0,902$ dan 0,806. Untuk nilai $t_{\text {hitung }}$ ATVA ( $\mathrm{t}=60$ ) sebesar 1,813 yang berada di dalam t-tabel 2 sisi 0,05 $(2,0345)$. Nilai signifikansi (2tailed) sebesar 0,107, yang berarti lebih besar dari nilai alpha 0,05. Sedangkan nilai rata-rata dari ATVA 60 hari sebelum dan sesudah right issue pada kelompok bad news adalah sebesar 0,758 dan 0,781 . Untuk nilai $t_{\text {hitung }}$ ATVA $(\mathrm{t}=60)$ sebesar $\quad-0,555 \mathrm{yang}$ berada di dalam t-tabel 2 sisi 0,05 $(2,0345)$. Nilai signifikansi (2tailed) sebesar 0,584, yang berarti lebih besar dari nilai alpha 0,05. Dengan demikian, dapat disimpulkan bahwa tidak terdapat perbedaan yang signifikan antara nilai rata-rata dari ATVA 60 hari sebelum dan sesudah right issue pada kelompok good news dan bad news.

Pada hasil perhitungan ATVA $(\mathrm{t}=90)$. Nilai rata-rata dari ATVA 90 hari sebelum dan sesudah right issue pada kelompok good news adalah sebesar $\quad 0,905$ dan 0,807 . Untuk nilai $t_{\text {hitung }}$ ATVA $(\mathrm{t}=90)$ sebesar 1.541 yang berada di dalam t-tabel 2 sisi $0,05(2,0345)$. Nilai signifikansi (2-tailed) sebesar 0,162 , yang berarti lebih besar dari nilai alpha 0,05 . Sedangkan nilai rata-rata dari ATVA 90 hari sebelum dan sesudah right issue pada kelompok bad news adalah sebesar 0,731 dan 0,761. Untuk nilai $t_{\text {hitung }}$ ATVA $(t=90)$ sebesar
-0,679 yang berada di dalam ttabel 2 sisi $0,05 \quad(2,0345)$. Nilai signifikansi (2-tailed) sebesar 0,504 , yang berarti lebih besar dari nilai alpha 0,05 . Dengan demikian, dapat disimpulkan bahwa tidak terdapat perbedaan yang signifikan antara nilai rata-rata dari ATVA 90 hari sebelum dan sesudah right issue pada kelompok good news dan bad news.

Tabel 2 juga memperlihatkan ATVA $(\mathrm{t}=180)$. Nilai rata-rata dari ATVA 180 hari sebelum dan sesudah right issue pada kelompok good news adalah sebesar 0,882 dan 0,823 . Untuk nilai $t_{\text {hitung }}$ ATVA ( $\mathrm{t}=180)$ sebesar 1,020 yang berada di dalam t-tabel 2 sisi 0,05 $(2,0345)$. Nilai signifikansi (2tailed) sebesar 0,338, yang berarti lebih besar dari nilai alpha 0,05 . Sedangkan nilai rata-rata dari ATVA 180 hari sebelum dan sesudah right issue pada kelompok bad news adalah sebesar 0,719 dan 0,739. Untuk nilai thitung ATVA $(\mathrm{t}=180)$ sebesar $-0,435$ yang berada di dalam t-tabel 2 sisi 0,05 $(2,0345)$. Nilai signifikansi (2tailed) sebesar 0,668 , yang berarti lebih besar dari nilai alpha 0,05 . Dengan demikian, dapat disimpulkan bahwa tidak terdapat perbedaan yang signifikan antara nilai rata-rata dari ATVA 180 hari sebelum dan sesudah right issue pada kelompok good news dan bad news.

\section{Pembahasan}

Pengujian terhadap abnormal return dan trading volume activity dilakukan dengan menggunakan one sample t-test dan paired sample t-test. Untuk pengujian terdapatnya abnormal return dan trading volume activity sebelum dan sesudah right issue digunakan One sample t-test dan pengujian terdapatnya perbedaan 
abnormal return dan trading volume activity sebelum dan sesudah right issue digunakan paired sampel t-test.

\section{a. Pengujian abnormal return sebelum dan sesudah} pengumuman right issue

Dari hasil analisis terlihat bahwa average abnormal return mengalami penurunan selama waktu pengamatan yaitu 5 hari, 15 hari, 60 hari, 90 hari, 180 hari sebelum dan setelah dilakukannya right issue pada kelompok saham good news dan bad news. Hasil penelitian AAR ini menunjukkan bahwa tidak terdapat perbedaan yang signifikan antara rata-rata abnormalreturn sebelum dan ratarata abnormal return setelah dilakukannya right issue. Hal ini memperlihat kan secara umum tidak terdapatnya perubahan atau perbedaan abnormalreturn sebelum dan setelah dilakukan nya pengumuman right issue.

Hasil ini memperlihatkan pada waktu periode pengamatan 5 hari, 15 hari, 60 hari, 90 hari dan 180 hari sebelum dan setelah dilakukannya right issue tidak terdapatnya perbedaaan yang signifikan terhadap Abnormal returnpada kelompok saham good news dan bad news yang menunjukan bahwa return yang didapatkan oleh investor sebelum rightissue tidak berbeda jauh dengan return setelah dilakukan rightissue. Hal ini berarti bahwa pengumuman rightissue tidak memiliki kandungan informasi yang mengindikasikan adanya informasi yang tidak menguntungkan (badnews) tentang kondisi laba di masa akan datang yang dapat meningkatkan abnormalreturn secara signifikan, dan juga informasi right issue tidak mempunyai kandungan informasi yang menyebabkan terjadinya perbedaan dalam preferensi investor.

Hasil penelitian ini konsisten dengan hasil penelitian yang dilakukan oleh Zulfadli (2009) bahwa tidak terdapat perbedaan abnormal return yang signifikan antara periode pengamatan 5 hari, 15 hari, 90 hari, dan 180 hari sebelum dan sesudah right issue terhadap abnormal return.

b. Pengujian trading volume activity sebelum dan sesudah pengumuman right issue

Average trading volume activity mengalami penurunan selama waktu pengamatan yaitu 15 hari, 60 hari, 90 hari, 180 hari sebelum dan setelah dilakukannya right issue pada kelompok saham good news, sementara average trading volume activity mengalami peningkatan selama waktu pengamatan yaitu 15 hari, 60 hari, 90 hari, 180 hari sebelum dan setelah dilakukannya right issue pada kelompok saham bad news. Hal ini memperlihatkan bahwa secara umum tidak terdapatnya perubahan atau perbedaan trading volume activity sebelum dan setelah dilakukannya pengumuman right issue.

Pada hasil olahan data untuk periode pengamatan 5 hari sebelum dan setelah dilaku-kannya right issue pada kelompok saham good news terlihat ATVA mengalami penurunan setelah dilakukannya right issue. Sedangkan pada kelompok saham bad news juga terlihat bahwa ATVA mengalami peningkatan secara signifikan setelah dilakukan right issue. Hasil penelitian menunjukkan bahwa terdapat perbedaan antara sebelum dan setelah dilakukannya right issue pada kelompok saham good 
news. Hal ini memperlihatkan terdapat perbedaan trading volume activity yang signifikan sebelum dan sesudah dilakukannya right issue pada kelompok saham bad news.

Hasil ini menunjukan bahwa return dan tingkat likuiditas saham sebelum right issue tidak berbeda jauh dengan return dan tingkat likuiditas saham setelah dilakukan right issue. Hal ini berarti bahwa pengumuman right issue tidak memiliki kandungan informasi yang mengindikasikan adanya informasi yang tidak menguntungkan (badnews) tentang kondisi laba di masa akan datang yang dapat meningkatkan abnormal return dan trading volume activity secara signifikan, dan juga informasi right issue tidak mempunyai kandungan informasi yang menyebabkan terjadinya perbedaan dalam preferensi investor.

\section{SIMPULAN DAN IMPLIKASI PENELITIAN}

Berdasarkan hasil pengolahan data dan pembahasan terhadap hasil penelitian yang dilakukan melalui uji paired sample t-test antara right issue dengan abnormalreturn dan trading volume activity, maka dapat disimpulkan bahwa tidak terdapat perbedaan abnormal return yang signifikan pada Periode Pengamatan 5 hari, 15 hari, 60 hari, 90 hari, 180 hari sebelum dan 5 hari, 15 hari, 60 hari, 90 hari, 180 hari sesudah right issue pada kelompok saham good news dan bad news. Maka dapat disimpulkan bahwa aktivitas pengumuman right issue tidak memberikan atau mempunyai kandungan informasi yang cukup untuk mempengaruhi abnormal return baik sebelum dan sesudah dilakukannya right issue.

Sementara pada trading volume activity, terdapat perbedaan trading volume activity yang signifikan pada periode 5 hari sebelum dengan sesudah pengumuman right issue pada kelompok saham bad news. Hal ini menunjukkan bahwa pengumuman right issue untuk kategori bad news mempunyai kandungan informasi yang cukup berarti sehingga mampu mengubah preferensi investor dalam mengambil keputusan investasinya. Hal ini terlihat pada rata-rata trading volume activity yang berbeda signifikan antara trading volume activity saham sebelum dengan sesudah pengumuman right issue.

Sampel dalam penelitian ini relatif sedikit. Penelitian selanjutnya peneliti dapat menambah jumlah sampel perusahaan dengan memperpanjang periode pengamatan sehingga pada hasil penelitian selanjutnya diharapkan lebih akurat karena mampu mencangkup keseluruhan data yang ada.selain itu, perlu mempertimbangkan variabel lain selain harga saham (abnormal return saham) dan volume perdagangan saham (TVA), antara lain: bid-ask spreads, rasio keuang-an, struktur modal dan juga aspek non-ekonomi serta politik yang dapat mempengaruhi preferensi investor dalam pengambilan keputusan manajerial.Pemisahan sektor perusahaan dan size perusahaan juga harus dipertimbangkan, sehingga dengan adanya pemisahan sektordan size, kemungkinan dapat memberikan sinyal positif kepada investor dengan adanya pengumuman right issue tersebut.

\section{DAFTAR PUSTAKA}

Ahmad, Kamaruddin. 1996. Dasardasar Manajemen Investasi. Jakarta: PT. Rineka Cipta. -2004. Dasardasar Manajemen Investasi dan Portopolio. Jakarta: PT. Rineka Cipta.

Brigham, Meugne. $F$ dan Joel F. Houston. 2001. Manajemen 
Keuangan Buku 1. Jakarta: Erlangga.

Budiarto, Arif dan Zaki Baridwan.1999.

Pengaruh Pengumuman Right

Issue terhadap Tingkat

Keuntungan dan Likuiditas

Saham Periode 1994-1996.

Jurnal Riset Akuntansi

Indonesia ( JRAI), Vol.3, No.1, Januari, Page 91-116.

Chae, J. (2005). Trading Volume, Information Asymmetry, and Timing Information. The Journal of Finance, Vol. 60, No. 1, Pp. 413-442.

Fahmi, Irham dan Yovi Lavianti Hadi. 2009. Teori Portopolio dan Analisis Investasi. Bandung: Alfa Beta.

Husnan, Suad dan Pudjiastuti, Enny. 2006. Dasar-dasar Manajemen Keuangan. Yogyakarta : BPFEYogyakarta.

Idris. 2006. Aplikasi Model Analisis Data Kuantitatif Dengan Program SPSS. Padang. Fakultas Ekonomi UNP.

Jogiyanto. 2003. Teori Portofolio dan Analisis Investasi, Edisi Ketiga. Yogyakarta: BPFE.

Moin, Abdul. 2007. Merger, Akuisisi dan Divestasi. Yogyakarta : Ekonosia

Raharja., \& Maylia. P. S. (2008). Kemampuan Rasio Keuangan dalam Memprediksi Peringkat Obligasi (PT Kasnic Credit Rating). Jurnal Maksi, Vol. 8, No. 2, pp. 212-232.

Samsul, Mohammad. 2006. Pasar Modal dan Manajemen Portofolio. Jakarta: Erlangga.

Sartono, Agus. 2001. Manajemen Keuangan Teori dan Aplikasi, Yogyakarta: BPFE- Yogyakarta.

Scott, W. R. (2003). Financial Accounting Theory. Upper
Saddle River, NJ: Prentice-Hall, Inc.

Siswanto, Heri. 1999. Studi Empiris tentang Pengaruh Pengumuman Right Issue terhadap Tingkat Keuntungan dan Likuiditas Saham Di Bursa Efek Jakarta Periode 1997-1999. Jurnal ekonomika

Solichin,Agus dan Imam Ghozali.2003. Analisis Dampak Pengumuman Right Issue Terhadap Reaksi Pasar di Bursa Efek Jakarta. Jurnal Ekonomi Perusahaan (JEP), Vol.10, No.1, Maret, Page 100-114.

Sunyoto. 2001. Pengaruh Emisi Right Issue terhadap Abnormal Return dan Volume Perdagangan Saham di BEJ,Tesis S2 UNDIP yang dipublikasikan. Semarang.

Tandelilin, Eduardus. 2001. Analisis investasi dan manajemen portopolio. Yogyakarta : BPFE Yogyakarta.

Portofolio dan Investasi: Teori dan Aplikasi. Yogyakarta: Kanisius Yogyakarta.

Tandelilin, E., \& I Wayan Nuka Lantara. (2001). Stabilitas dan Prediktabilitas Beta Saham: Studi Empiris di Bursa Efek Jakarta. Jurnal Ekonomi dan Bisnis Indonesia, Vol. 16, No.2, Hal. 164-176.

Yusi Sari, Prima. 2002. Right Issue dan Tingkat Keuntungan Saham Setelah Cum date. Jurnal Manajemen Indonesia (JMI), Vol.1, No.1,Page.72-81.

Zulfadli. 2009. Analisis Return Saham Sebelum dan Sesudah Right Issue pada Perusahaan Go Public di Bursa Efek Indonesia Tahun 2005-2009. Skripsi Manajemen. 